\title{
Quantitative Codicology and Scientific Paradigms. A Typology of Latin Formulae in the Colophons of Western Manuscripts
}

In a note published some ten years ago in the 'Gazette du livre médiéval', I announced a research project set within the framework of my doctoral thesis Etude sur le formulaire latin des colophons de manuscrits occidentaux (III $-X V I^{e}$ siècle). The publication of this work is currently in progress [Note of the editor: completed in 2006]. Accordingly, it seems timely to present, in the following pages, a preliminary methodological assessment of my investigations.

I will consider, successively, the most important results of my research, its specific methodology, and its methodological repercussions-namely the new codicological criteria that a clear understanding of the way in which colophon formulae 'functioned' can afford us. Finally, based on my experience while conducting the research, I shall make some remarks of a more epistemological nature.

\section{Results of the research}

Initially undertaken in order to portray the 'mindset' of copyists through their colophons-in other words, to see what anecdotal information might be drawn from them-my work quite soon became orientated towards a more typologically-based study. The notion that in colophons the copyists gave free rein to their natural expressiveness as a sort of protest against the arduousness of their work cannot be reconciled with the propensity towards formality in medieval men, nor with the hypothetical historical development of verbal formulae present in colophons. And yet, many scholars have accepted and perpetuated the preconceived idea of the anecdotal nature of colophon formulae and the notion of the scribes' spontaneity. An important part of the reason behind their use could

Translated from the French into English by Mark Livesey. Original published as Reynhout, Lucien (2001), 'Codicologie quantitative et paradigmes scientifiques: une typologie des formules latines de colophons de manuscrits occidentaux’, in Gazette du livre médiéval, 39, 1-11.

1 Reynhout 1988.

D Open Access. (C) 2022 Lucien Reynhout, published by De Gruyter. (c) BY-NC-ND This work is licensed under the Creative Commons Attribution-NonCommercial-NoDerivatives International 4.0 International License. https://doi.org/10.1515/9783110743838-019 
instead have to do with the need to adhere to stereotypes. In carrying out a systematic perusal of Bénédictins du Bouveret's Colophons de manuscrits occidentaux, it became apparent to me that the formulae were used to fulfil specific functions, since they include relatively precise datings and localisations. Furthermore, the aforesaid specific uses appeared to correspond very closely to the major periods of cultural history in the Latin West, from the end of the classical age up until the Renaissance. In some cases, very close parallels can also be established with major historical milestones in the history of Latin writing. So much, then, for intuition: it was still necessary to develop a reliable method to prove my thesis! For the time being, and without presuming that my text will be published in its entirety, to begin with I would like to identify the main junctures in the history of the system of colophon formulae employed in Western manuscripts.

The history begins with the most ancient witnesses that have come down to us from Imperial Rome's book trade. The word feliciter employed in the colophons of manuscripts bearing Latin classics betrays the influence of the lexicon used in Roman religion. At least four variants exist: Explicit ... feliciter, Lege feliciter, (verb) + feliciter and utere feliciter. The last-mentioned formula is found particularly in the epigraphical part of the instrumentum, which is to say the group of inscriptions placed on handcrafted items, where it serves a propitiatory function. It is striking to observe that, in some of the rarest and relatively late examples, one encounters phrases such as Explicit feliciter in Christo, which testify to a form of cultural adaptation of the classic slogan of pagan inspiration, which was used in Christian circles-a phenomenon that can be likened to the adaptation of a classical scholarship culture in a Christian context. However, before long specifically Christian formulae began to appear. In particular, there is the case of Orate pro scriptore si(c) Deum habeatis protectorem, where it pleased Michel Huglo to discern an epigraphical origin. ${ }^{2}$ Contrarily, in my view it is in liturgical language and that of the Church Fathers where one can find the source of inspiration for these formulae. Two interesting points should be noted. The most ancient witness (Firenze, Biblioteca Medicea Laurenziana 65, 1, f. 144v) is inscribed by a certain Viliaric, who qualifies himself as antiquarius ... in statione, and was beyond doubt active at Ravenna in the $6^{\text {th }}$ century. Now, as everyone knows, members of the Ostrogoth elite adapted themselves to what remained of ancient society by progressively developing towards the inception of the Middle Ages. The same formula was still frequently employed in the Carolingian age and, indeed, up until around the $10^{\text {th }}$ century. Subsequently, the formula disappears. The sole exception is on the Iberian Peninsula, where it en-

2 Huglo 1961. 
dured until the $12^{\text {th }}$ century! The Principalities of Catalonia and Spain effectively found themselves under the suzerainty of the Frankish kings, whose hallmarks they bear, especially in the formulae of diplomatic acts, up until, indeed, the $12^{\text {th }}$ century. But later on, being conscious of these signs, the principalities rid themselves of the last vestiges of this dependence. ${ }^{3}$ Without doubt, our formula met with the same fate, which explains its total disappearance after the dawn of the $13^{\text {th }}$ century.

The Carolingian Age saw the appearance of rather more 'technical' terms to describe the act of transcriptions, such as transcriptus, expletus, etc. In general, the use of these terms was certainly not limited to the $8^{\text {th }}, 9^{\text {th }}$ and $10^{\text {th }}$ centuries. In particular, one encounters them in the lexicons of the Latin Fathers. In colophons, however, they are not seen before the $8^{\text {th }}-9^{\text {th }}$ centuries. Nevertheless, a reconciliation was achieved: learned Carolingians sought ancient models, both intellectual and stylistic, in just the same way that the Humanists would some six centuries later.

With the dawn of the $12^{\text {th }}$ century and the revival of scholastic culture, ${ }^{4}$ a new family of formulae appeared that Denis Muzerelle has termed ritournelles (i.e. refrains). ${ }^{5}$ If some of the formulae seem somewhat Italianate (such as Finito libro sit laus et gloria Christo) or Germanic (such as Finis adest operis, mercedem posco laboris), others are clearly informed by a French influence, such as Explicit, expliceat, ludere scriptor eat; Explicit iste liber, sit scriptor crimine liber or Detur pro penna scriptori pulchra puella. Notwithstanding the very wide distribution of these formulae in the $13^{\text {th }}$ to $14^{\text {th }}$ centuries and the fact that their largely anonymous use makes them impossible to localise, one can discern, through the content of the associated texts, the very clear influence of the milieus of both the cathedral school and the University of Paris. It should be noted that elsewhere alternating 'pious' and 'satirical' variants can be seen which are fully in the spirit of the Goliards.

On the other hand, the Late Middle Ages would see an increase in specific formulae in more circumscribed geographical areas. 'National', as it were, cultures began to assert themselves. Thus, the formulae Finito libro referatur gratia Christo and Qui scripsit scribat, semper cum Domino uiuat are certainly of $13^{\text {th }}$ to $14^{\text {th }}$ century Italian origin. Regarding the latter formula, its use in Provence, Languedoc, Aquitaine and the north of the Iberian Peninsula (i.e. Catalonia) should be seen in parallel with the area of dispersion of scriptura gothica rotunda, and with the influence of the early Italian Renaissance on the other contemporary

\footnotetext{
3 Zimmermann 1981.

4 See, in particular, Paré / Brunet / Tremblay 1933.

5 Muzerelle 1985, 137, No. 435.11.
} 
southern cultures of the Avignon Papacy: Dante, for example, served as a model for the father of Catalonian poetry, Auzias March, one of whose manuscripts represents part of our sample. Additionally, one finds elsewhere ...cuius animae propitietur Deus, which seems to be confined to the English area, and Nomen scriptoris... plenus amoris, in the Anglo-Norman domain. The area of diffusion of the formulae Finitus et completus... and Oretis pro scriptore propter Deum is limited to the old Low Countries and North-West Germany. In the latter case, the link between that geographical area and the Carthusian Order is clear. This is also the area of dispersion of the seats of the Devotio moderna (i.e. Brethren of the Common Life, Windesheim Congregation). One is conscious of the importance of book transcription to this spiritual movement, an appetite which was largely inspired by the Carthusian Order. ${ }^{6}$ Therefore, we can readily imagine the impact that spiritual and cultural trends had on the use of colophon formulae.

Finally, the Renaissance saw the emergence of a three-fold phenomenon: the resurgence of certain ancient formulae with renewed vigour, the adoption of formulae of Carolingian origin which had fallen into disuse, and the creation of formulae specific to humanist milieus. Thus, Feliciter, which was chiefly associated with classical content throughout almost the entire duration of the Middle Ages, exhibits a very significant rate of association (more than 20\%) with the texts of contemporary authors (i.e. humanists), starting at the end of the $14^{\text {th }}$ century and extending into the $15^{\text {th }}$, thereby providing clear evidence of an appropriation of this usage. Transcriptus, a formula which had disappeared between the $11^{\text {th }}$ and $14^{\text {th }}$ centuries, reappeared in a very visible way in the $15^{\text {th }}$ century, and likewise was employed particularly in humanist milieus.

As can be seen, the functional division of formulae through space and time is clearly identifiable. Links to the main cultural trends sometimes make themselves apparent in a striking way. Therefore, this placing in perspective of colophon formulae by means of a qualitative methodological approach definitively precludes their supposedly anecdotal nature.

\section{Methodology}

The methodology adopted bears the stamp of 'quantitative codicology'. This approach aims at selecting the indicators associated with a particular phenomenon, at describing their values in a uniform way across a representative population, and at

6 Lourdaux 1963a; Lourdaux 1963b. 
measuring their manifestations. However, the statistical approach is not entirely adequate to the task. Indeed, it is still necessary to explain the phenomenon in relation to the cultural context concerned. In the sphere of codicology, this methodology has been applied in the observation of material facts that are readily quantifiable (i.e. ruling, justification, the number of lines per page, etc.). In our case, one is working with elements of a textual nature. The only area in which a similar methodology has been introduced is that of 'quantitative' lexicography, where the units one is working with are literary texts. In the case of colophons, one is likewise dealing with a text, although of a very marked documentary nature. Accordingly, we find ourselves in the realm of the stereotype and the replication of frameworks (in other words, in contrast to the lexicon of literary texts, in the case of colophons one will encounter only a few different terms whose usage rates are very significant). Furthermore, the lexical unit is not represented by the word or the form, but rather by the formula, which is to say a characteristic verbal sequence. The problem arises because neither the thematic unity nor the identity of terms alone is sufficient to identify a formula. It is usually a characteristic 'family appearance' that determines the typology.

Once the formulae have been identified, one must still establish their attestation grouping trends. In order to achieve this, it is necessary to isolate some indicators that represent such trends, namely the copyist's place of origin, along with that of the manuscript, the dating of both the text and of the transcription as stated in the colophon (these two dates may be different if the copyist reproduced the colophon from his model, as unfortunately was often the case), the textual content and other historical constituents of the manuscript, all of which are 'contextualisation' elements that shed light on the use of colophon formulae. The next step is to calculate the frequency with which a given factor appears, or the correlation of several factors combined.

Largely speaking, the methodology is widely known. All the same, it should be pointed out that it has never been applied to such a large sample (consisting of 6,000 to 7,000 colophon attestations). At the same time, contextualisation is not always a simple matter, nor is it entirely unequivocal. But all things considered, the most important goal is to identify some trends and functional distinctions. Finally, the ultimate step to carry out in the survey is without doubt the most sensitive one, namely the interpretation of the results. In order to gain an understanding of the system's governing logic, one must explain why the groupings are as they are through the application of an interpretative grid. 


\section{Methodological repercussions}

The broad historical canvas set out above is not the only product of the present research. The study of colophon formulae also exerts an influence on the methodological plan, and therefore requires the establishment of new expertise criteria for manuscript dating and localisation, the identification of the role played by factors of a cultural nature on codicological phenomena, and a recognition of the notion that for a given codicological phenomenon there exist external determining factors (e.g. historical or economic), as well as endogenous mechanisms which can explain development. Finally, it becomes possible to build bridges between the various disciplines concerned with the history of writing, such as epigraphy and diplomacy, where we know that characteristic formulae were also employed.

New expertise criteria. The relative datings and localisation of colophon formulae will in fact make it possible to attain implicit datings and localisations for manuscripts whose colophons do not furnish precise information. Additionally, the systematic validation of the dating and localisation of colophon formulae holds the promise of creating some new codicological criteria, which up until now have not been exploited. However, one should not imagine that such new criteria will make it possible to replace the already established criteria; rather, they will play a complementary role. That being said, in some cases they could shed some additional light on matters, albeit of a secondary kind.

Cultural factors. The thinking behind the use of colophon formulae is also worth reflecting on. Economic or technical factors were not the only ones to exert an influence on the shaping of the material characteristics of the manuscript book. Indeed, the field is wide open, not only to the spontaneity of the artisans but also to the application of cultural patterns. In the choice of these, stylistic factors doubtless played a role that was no less important than material constraints. In the case of colophons, the copyists sought not so much what was unequivocal and consistent information on the transcription of the manuscript, but rather the best response possible to prevailing cultural models. Hence, in different periods and at different locales, one can observe formulae and variants cast from the same mould. This can be explained by the influence of cultural phenomena which have parallels in the development of writing types or the decoration of manuscripts, or even in architectural forms or major trends in contemporary intellectual history. Needless to say, this concerns the history of mindsets as much as that of techniques. 
Endogenous mechanisms. Alongside the influence of cultural factors, one should be careful not to overlook the influence of endogenous mechanisms. In the birth, development, decline and ultimate demise of formulae there are some very real mechanisms at play-some highly distinctive functional frameworks. This is true, for example, of the division into variants of one and the same formula: the birth of several concurrent variants, with one eventually winning out over the others; the alternation of variants over time, with the decline of one appearing to usher in the rise of another; and the geographical division into cultural subdomains, with one or another amassing more attestations of a given type of variant (this, in turn, representing a more precise localisation index than the formula). If one were bold enough to venture an epistemological parallel, one could almost compare the mechanisms that govern the 'lives' of the formulae to manifestations of a biological nature!

Multidisciplinary potential. Finally, it should be emphasised that from a methodological standpoint, the study of colophon formulae can contribute to building bridges between the different areas of study concerned with the history of writing. We have seen how the use of certain formulae is just as well established in the work of book scribes as it is in that of chancellery clerks or lapicides. In the colophons themselves, certain formulae are shared by different cultural domains and civilisations, such as the formula Sicut nauigantibus portus, sic scriptori nouissimus uersus, whose equivalent is found in Greek, Southern Slavic, Syrian, and Arab Christian domains. The direction of their shift from one domain to another and the chronology of their 'migrations' would certainly contribute to helping us to better understand the reciprocal influences of the above-mentioned cultures. More broadly speaking, this study aims to reach beyond epistemological limits in at least three ways: namely disciplinary boundaries, boundaries between cultures, and finally temporal limits.

\section{Epistemological remarks}

To conclude, I shall now outline some considerations of a more epistemological nature. For the benefit of scholars, with respect to colophon formulae dating from the $11^{\text {th }}$ century onwards, we can identify two distinct approaches and three stages in the development of a scientific theory. One of these approaches is of a historical nature and takes into account only the explicit information on colophons derived from research which is not based on the colophons themselves. This can be clearly understood by reading the proceedings of the Erice conference on scribes and 
colophons: ${ }^{7}$ from colophons one can extract information on the world of copyists, their status, and potentially their mindset. There are other examples which make it possible to write a history of manuscript manufacture and techniques, or of the production of books in certain milieus. At the same time, though, one must regard colophons as a sui generis phenomenon and place an emphasis on the study of their internal structure, terminology, and the ways in which they were employed. It is worth noting that the oldest contribution to this approach was made by Otto Jahn ${ }^{8}$, who in the mid- $19^{\text {th }}$ century was already pondering the role played by the prosopography of ancient colophons in critical philology.

However, the first scholar to take a close look at the formulae employed in colophons was Wilhelm Wattenbach in a chapter of his Schriftwesen im Mittelalter. ${ }^{9}$ In this work one senses his intuition for the dating and localisation of colophons. In fact, one encounters phases such as 'vorzüglich in späterer Zeit', 'Später ist sehr gewöhnlich', and 'Schon dem Alterthum gehört'. Unfortunately, his comments are replete with value judgements: 'Besser, wenn auch noch incorrect...', 'Hübsch...', '...der sinnlose Scherz...', 'In etwas eidlicheren Versen...', 'Zu den harmlosen Scherzen gehört...', etc. Essentially, Wattenbach failed to bring historical coherence to his approach. An anecdotal perception of formulae in colophons ensued which, by means of a curious mechanism, was perpetuated in the work of various scholars following in Wattenbach's footsteps up until just before the dawn of the $20^{\text {th }}$ century, a little as if a koiné had been established that was never called into question. Be it in the work of Alphonse De Poorter, Lynn Thorndike, Antoine Dondaine, Louis Laurand, Arthur Långfors or André Boutemy, ${ }^{10}$ one gets the feeling that this rather spontaneous theory of formulae had been installed for good. Nothing more than an idea was being repeated, with attempts made to support it by using other examples, the more of which there were, the more persuasive the theory. Only Gérard Garitte ${ }^{11}$ in the Greek domain, and Michel Huglo ${ }^{12}$ in the Latin, called this theory into question. The two scholars were driven by a hunch that, it should be noted, was not based on a quantity of witnesses much greater than that used by their predecessors. A systematic approach applied to a large number of sources would be necessary in order to be able to identify some clear trends to support the notion that the use of colophons was anything but anecdotal.

7 Condello / De Gregorio 1995.

8 Jahn 1851.

9 Wattenbach 1896.

10 De Poorter 1935; Thorndike 1937; Thorndike 1956; Dondaine 1978; Laurand 1933, 108, 115, 116; Långfors 1936; Boutemy 1934-1935.

11 Garitte 1962.

12 Huglo 1954. 
What is rather surprising is that if one applies an interpretative grid to the history of our theme one essentially observes the same pattern as that seen in the so-called 'exact' sciences. In fact, according to Thomas Kuhn, ${ }^{13}$ the development of science progresses in a series of steps in which theories are devised, only to be followed by periods of stagnation while a new theory forms into a paradigm, and finally, on the heels of new experimental evidence that calls into question the basis of the previous paradigm, the birth of a new theory. This is known as a 'theoretical revolution'. The phenomenon we observe in our study of colophons is analogous. The 'historical' theory (i.e. that colophons contain explicit pieces of information) and the theory that views colophons as being anecdotal in nature (i.e. that they naturally express the personalities and mindset of the copyists) seemingly coexist without being connected. The latter view becomes a paradigm and is repeated ad infinitum, without being supported by scientific investigation and evidence. One day a new hunch may emerge that is also lacking any scientific basis. To conclude, only the processing of valid sources on a large scale makes it possible to support a new theory-one which will be supplementary to the 'historical' theory, but in total contradiction of the previous supposition. Thus, any advances made by us in our various fields of study will not be built on progressive accumulation, but instead on the perennial necessity to examine reality and to call into question ideas which have all too readily been accepted as gospel.

\section{References}

Boutemy, André (1934-1935), 'Un grand abbé du XI' siècle: Olbert de Gembloux', in Annales de la Société archéologique de Namur, 41: 43-85.

Condello, Emma / De Gregorio, Giuseppe (eds) (1995), Scribi e colofoni: le sottoscrizioni di copisti dalle origini all'avvento della stampa. Atti del seminario di Erice, $\mathrm{X}$ Colloquio del Comité international de paléographie latine (23-28 ottobre 1993), Spoleto: Centro Italiano di studi sull'alto medioevo.

De Poorter, Alphonse (1935), 'Quelques formules à l'usage des scribes et annotations diverses tirées des manuscrits de Bruges', in Revue belge de philologie et d'histoire, 14: 872-879.

Dondaine, Antoine (1978), 'Post-scriptum', in Scriptorium, 32: 54-55.

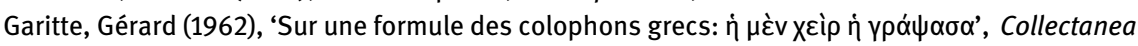
Vaticana in honorem Anselmi M. Card. Albareda a Bibliotheca Apostolica edita, Città del Vaticano: Biblioteca Apostolica Vaticana (Studi e Testi, 219): 359-390.

Huglo, Michel (1954), 'Christe fave votis', in Scriptorium, 8: 108-111.

13 Kuhn 1983. 
Huglo, Michel (1961), 'Origine épigraphique d'une note de copiste', in Hispania sacra: Revista de historia ecclesiástica, 14: 444-451.

Kuhn, Thomas S. (1983), La structure des révolutions scientifiques. (Trad, de l'américain par L. Meyer), Paris: Flammarion (Champs, 115).

Jahn, Otto (1851), 'Über die Subscriptionen in den Handschriften römischer Classiker’, in Berichte über die Verhandlungen der Königlich Sächsischen Gesellschaft der Wissenschaften zu Leipzig, Philol.-hist. Cl., 3: 327-372.

Långfors, Arthur (1936), 'À propos des explicits des manuscrits de la Bibliothèque de Bruges', in Neuphilologische Mitteilungen, 37: 1-15.

Laurand, Louis (1933), 'Les manuscrits de Cicéron', in Revue des études latines, 11: 92-128.

Lourdaux, Willem (1963a), 'Enkele beschouwingen over de betrekkingen tussen Kartuizers en Moderne Devoten', in Handelingen van het XXV Vlaams Filologencongres (Antwerpen 1719 april 1963), Leuven: Drukkerij M. \& L. Symons, 416-422.

Lourdaux, Willem (1963b), 'Kartuizers - Moderne Devoten: een probleem van afhankelijkheid', in Ons Geestelijk Erf, 37: 402-418.

Muzerelle, Denis (1985), Vocabulaire codicologique. Répertoire méthodique des termes français relatifs aux manuscrits. Paris: CEMI (Rubricae. Histoire du livre et des textes, 1).

Paré, Gérard / Brunet, Adrien Marie / Tremblay, Pierre (1933), La renaissance du XII siècle: les écoles et l'enseignement. Refonte complète de l'ouvrage de Gaston Robert. Paris: Vrin (Publications de l'Institut d'études médiévales d'Ottawa, 3).

Reynhout, Lucien (1988), 'Pour une typologie des colophons de manuscrits occidentaux', in Gazette du livre médiéval, 13: 1-5.

Thorndike, Lynn (1937), 'Copyists' Final Jingles in Mediaeval Manuscripts', in Speculum, 12: 268.

Thorndike, Lynn (1956), ‘More Copyists' Final Jingles', in Speculum, 31: 321-328.

Wattenbach, Wilhelm (1896), Das Schriftwesen im Mittelalter. $4^{\text {th }}$ edition, Graz: Akademische Druck u. Verlagsanstalt [reprint. $3^{\text {rd }}$ edition, Leipzig 1896.]

Zimmermann, Michel (1981), 'La datation des documents catalans du IX' au XII' siècle: un itinéraire politique’, in Les Annales du Midi, 93: 345-375. 